\title{
USULAN PENERAPAN METODE SIX SIGMA UNTUK MENINGKATKAN MUTU CRUDE PALM OIL (CPO) DI PT. X
}

\author{
Wawan Kurniawan, Dedy Sugiarto dan Ricky Saputera \\ Teknik Industri FTI Universitas Trisaktil \\ e-mail: wawan_bdb2@yahoo.com
}

\begin{abstract}
ABSTRAK
PT. X merupakan perusahaan pengolahan kelapa sawit menjadi Crude Palm Oil (CPO). Pada proses pengolahan CPO perusahaan masih mengalami permasalahan dalam pencapaian standar mutu CPO yaitu masih rendahnya tingkat pencapaian norma untuk kandungan kadar Asam Lemak Bebas (ALB). Kandungan kadar ALB yang terdapat pada produksi CPO seringkali melebihi norma maksimal yang telah ditetapkan sehingga menyebabkan penurunan mutu dari produksi CPO. Norma maksimal untuk kandungan kadar ALB 3,5\% yang diizinkan dalam setiap produksi CPO. Tujuan dilakukan penelitian ini untuk mengidentifikasi faktor-faktor penyebab kenaikan kadar ALB yang melebihi norma maksimal dan memberikan usulan perbaikan untuk peningkatan mutu CPO. Upaya yang dilakukan untuk mengatasi permasalahan tersebut yaitu dengan menggunakan pendekatan metode Six Sigma melalui tahapan DMAIC (define, measure, analyze, improve, control). Perbaikan untuk mengatasi permasalahan yang ada yaitu berupa perbaikan secara berkelanjutan yaitu perbaikan bahan baku, tenaga kerja, lingkungan dan mesin
\end{abstract}

Kata kunci: Kelapa sawit, Asam Lemak Bebas (ALB), DMAIC (define, measure, analyze, improve, control)

\section{ABSTRACT}

PT. $X$ is a palm oil processing company to be Crude Palm Oil (CPO). In the process of CPO processing companies still experience problems in achieving CPO quality standards that is still low level of achievement norms for content content of Free Fatty Acid (ALB). The content of ALB levels contained in $C P O$ production often exceeds the predetermined maximal norm causing a decrease in the quality of $C P O$ production. The maximal norm for ALB content of 3.5\% is permitted in any CPO production. The purpose of this research is to identify the factors causing the increase of ALB level that exceed the maximal norm and to propose improvement for CPO quality improvement. Efforts are made to overcome the problem is by using the approach of Six Sigma method through the stages of DMAIC (define, measure, analyze, improve, control). Improvement to overcome the existing problems that is in the form of continuous improvement that is the improvement of raw materials, labor, environment and machinery

Keywords: Oil palm, Free Fatty Acid (ALB), DMAIC (define, measure, analyze, improve, control)

\section{PENDAHULUAN}

Indonesia merupakan salah satu negara penghasil minyak Crude Palm Oil (CPO) terbesar di dunia yang berasal dari perkebunan kelapa sawit. Dalam mengembangkan usaha perkebunan kelapa sawit, Indonesia saat ini tidak hanya mengembangkan kelapa sawit dalam bentuk usaha perkebunan. Perkembangan usaha perkebunan kelapa sawit di Indonesia telah mengalami kemajuan yang sangat signifikan hal ini ditunjukkan dengan banyaknya perusahaan yang mendirikan Pabrik Kelapa Sawit (PKS) dan makin banyaknya ragam produk yang bisa dihasilkan dari kelapa sawit sehingga dapat meningkatkan nilai jual dari produk. Dengan perkembangan usaha perkebunan kelapa sawit diharapkan secara ekonomi bisa memperbesar kontribusi dalam meningkatkan kesejahteraan masyarakat dan sebagai salah satu sumber penghasil devisa negara.

Peningkatan terhadap permintaan CPO baik dari pasar dalam negeri maupun luar negeri mendorong perusahaan untuk meningkatkan kapasitas produksi CPO. Tingginya permintaan CPO menimbulkan dampak persaingan bisnis diantara produsen CPO. Upaya yang dilakukan perusahaan dalam memenuhi permintaan CPO yaitu dengan pemanfaatan perkebunan kelapa sawit secara optimal untuk meningkatkan kapasitas produksi. Selain meningkatkan kapasitas produksi CPO, perusahaan dituntut untuk memproduksi CPO dengan mutu yang baik 
guna meningkatkan daya saing perusahaan. Mutu CPO dikatakan baik apabila memenuhi standar mutu yang telah ditetapkan. Standar mutu dari CPO yang diperhatikan berupa kadar Asam Lemak Bebas (ALB), kadar air dan kadar kotoran yang terdapat dalam produksi CPO tidak melebihi norma maksimal yang telah ditetapkan.

PT. X merupakan perusahaan bidang pengolahan kelapa sawit menjadi CPO. Dalam proses pengolahan masih ditemukan permasalahan yang menjadi latar belakang dalam penelitian tugas akhir ini berupa belum tercapainya secara maksimal standar mutu CPO yang diproduksi sehingga berpengaruh terhadap mutu dari produksi CPO. Upaya untuk meningkatkan mutu dari produksi CPO yaitu dengan melakukan penelitian fokus pada standar mutu CPO yang belum tercapai secara maksimal. Dalam mengatasi permasalahan menggunakan pendekatan metode Six Sigma. Six Sigma merupakan metode yang bertujuan untuk mengurangi variasi dari suatu proses dengan melakukan perbaikan secara terus menerus sehingga dapat meningkatkan kemampuan proses perusahaan.

\section{Pokok Permasalahan}

Berdasarkan penelitian dilapangan dengan melakukan wawancara maupun dengan pengamatan secara langsung, ditemukan pokok permasalahan dalam penelitian tugas akhir ini berupa masih belum tercapainya secara maksimal standar mutu CPO yang diproduksi di PT. X khususnya pada pencapaian kadar ALB. Dimana kadar ALB yang terdapat pada produksi CPO masih di atas norma maksimal yang telah ditetapkan pabrik. Dimana norma maksimal pabrik untuk kadar ALB 3,5\% yang diizinkan dalam setiap produksi CPO, sehingga perlu dilakukan penelitian yang lebih lanjut untuk mengatasi kenaikan kadar ALB yang melebihi norma maksimal.

Tujuan penelitian yaitu mengidentifikasi faktor-faktor penyebab kenaikan kadar ALB pada proses pengolahan CPO dan memberikan usulan perbaikan untuk upaya peningkatan mutu CPO yang diproduksi dengan menekan kenaikan kadar Asam Lemak Bebas.

\section{Faktor yang Mempengaruhi Minyak Kelapa Sawit}

Minyak kelapa sawit yang disimpan akan mengalami penurunan mutu jika tidak ditangani dengan tepat, karena terjadinya reaksi oksidasi dan hidrolisis. Kerusakan yang terjadi pada minyak dapat disebabkan oleh beberapa faktor, seperti absorbsi bau dan kontaminasi, aksi enzim, aksi mikroba, serta dan reaksi kimia [1].

\section{Six Sigma}

Menurut Evans dan Lindsay [2] menyatakan bahwa Six Sigma paling tepat didefinisikan sebagai metode peningkatan proses bisnis yang bertujuan untuk menemukan dan mengurangi faktor-faktor penyebab kecacatan dan kesalahan, mengurangi waktu siklus dan biaya operasi, meningkatkan produktivitas, memenuhi kebutuhan pelanggan dengan lebih baik, mencapai tingkat pendayagunaan aset yang lebih tinggi, serta mendapatkan imbal hasil atas investasi yang lebih baik dari segi produksi maupun pelayanan. Sedangkan menurut Manggala [3] menyatakan bahwa Six Sigma merupakan sebuah metodologi terstruktur untuk memperbaiki proses yang difokuskan pada usaha mengurangi variasi proses (process variances) sekaligus mengurangi cacat (produk/jasa yang diluar spesifikasi) dengan menggunakan statistik dan problem solving tools secara intensif.

\section{METODE PENELITIAN}

Adapun metode penelitian ditunjukkan pada Gambar 1.

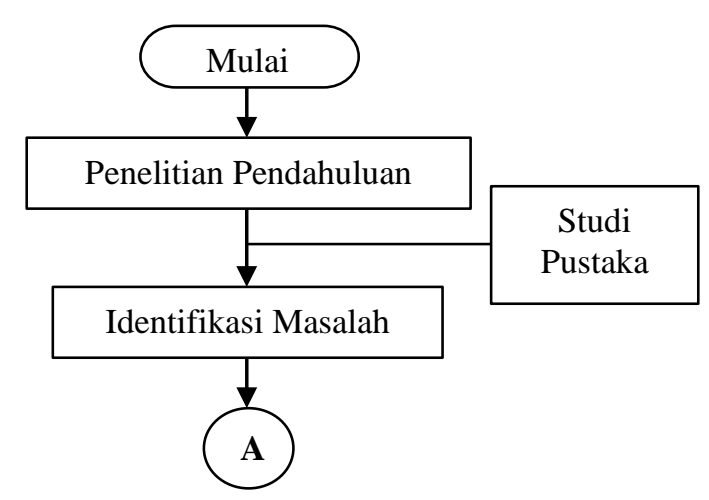

Gambar 1. Metode Penelitian 
Lanjutan Gambar 1. Metode Penelitian

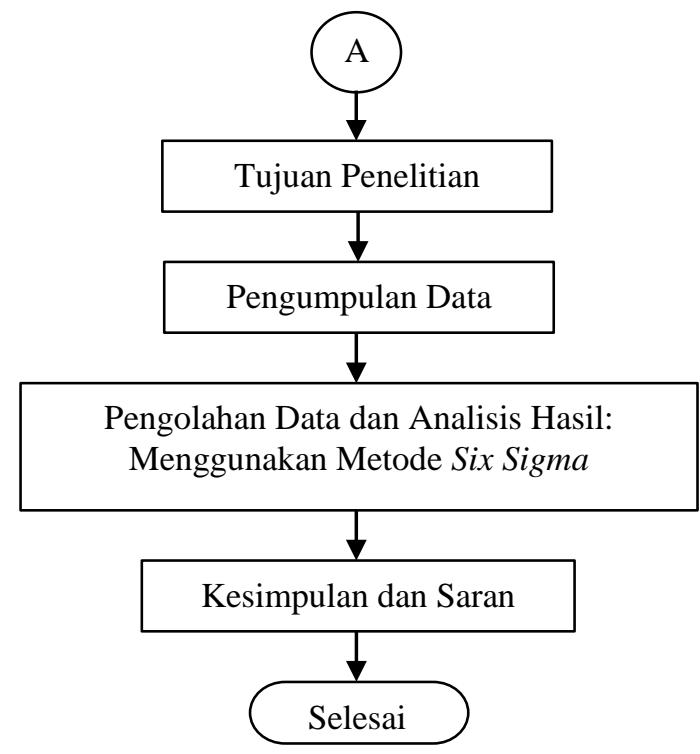

\section{PEMBAHASAN}

Proses produksi CPO PT $\mathrm{X}$ melalui beberapa tahapan proses pengolahan yang terdiri dari:
a. Penerimaan Buah (Fruit Reception)
b. Perebusan (Sterilizing)
c. Penebah (Threshing)
d. Pressan (Pressing)
e. Klarifikasi (Clarification)

Pengolahan data pada penelitina ini dengan menggunakan metode Six Sigma digunakan tahapan DMAIC (define, measure, analyze, improve, control). Define merupakan tahapan dalam mengidetifikasi permasalahan, measure digunakan untuk mengukur kapabilitas proses, analyze digunakan untuk menganalisa sebab akibat dari permasalahan yang ada, improve digunakan untuk memberikan usulan perbaikan terhadap permasalahan, dan kontrol digunakan untuk pengendalian secara menyeluruh dari semua tahapan DMAIC dengan tujuan untuk menjamin cacat tidak muncul

\section{Tahap Define}

a). Masih rendahnya tingkat pencapaian norma untuk kadar ALB dari produksi CPO.

b). Diagram SIPOC (Supplier Input Process Output Customer)

Diagram SIPOC digunakan untuk menjelaskan hubungan keterkaitan antara supplier, input, proses, output, dan customer yang terlibat dalam suatu proses bisnis. Diagram ini bertujuan untuk memberikan gambaran dan informasi secara umum tentang proses bisnis yang dilakukan, mulai dari supplier sampai ke customer. Berikut ini diagram SIPOC pada proses pengolahan CPO.

Tabel 1. SIPOC PT X

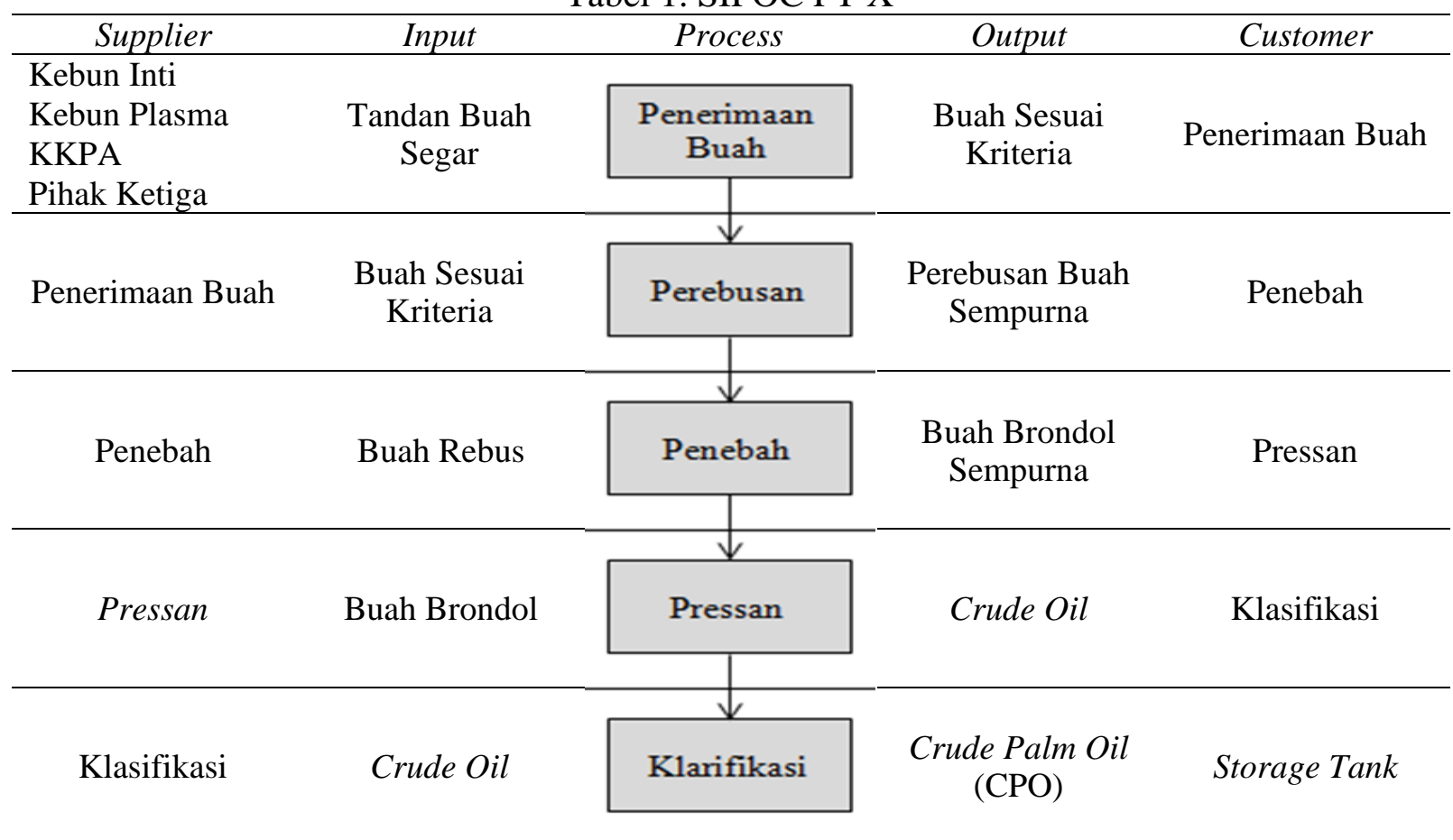




\section{Tahap Measure}

Tahap measure merupakan fase kedua dalam tahapan DMAIC yang terdapat pada Six Sigma. Dimana fase measure bertujuan untuk mengukur tingkat kinerja perusahaan saat ini. Pengukuran tingkat kinerja yang menjadi indikator dalam fase measure dalam penelitian ini berupa tingkat pencapai norma kadar ALB dalam produksi CPO, dimana norma maksimal untuk kadar ALB 3,5\% yang diizinkan dalam CPO.

\section{Kapabilitas Proses dan Konversi Level Sigma}

Setelah semua data kadar ALB berada dalam in control tahap selanjutnya yaitu perhitungan kapabilitas proses. Berdasarkan perhitungan kapabilitas diperoleh nilai Cpk sebesar 0,37 dimana dari nilai Cpk tersebut disimpulkan bahwa tingkat kapabilitas proses perusahaan masih sangat rendah, dan dapat disimpulkan juga bahwa perusahaan masih belum bisa memenuhi standar mutu CPO secara maksimal. Oleh karena itu perlu dilakukan analisa mengenai penyebab dari permasalahan yang terdapat pada perusahaan untuk perbaikan kedepannya. Berdasarkan tabel konversi diperoleh level sigma 1,10 dan disimpulkan level sigma masih sangat rendah.

\section{Tahap Analyze}

Tahap ini dengan menentukan input kritis dari suatu proses, melakukan analisa data serta proses, dan menentukan akar penyebab dari masalah yang menjadi target perbaikan.

\section{Diagram Sebab Akibat (Cause and Effect Diagram)}

Diagram sebab akibat merupakan suatu tools yang bertujuan untuk membantu dalam mencari dan menentukan akar dari penyebab potensial dari suatu masalah. Diagram ini juga disebut sebagai diagram fishbone atau Ishikawa. Gambar 2 merupakan diagram sebab akibat kenaikan kadar ALB dalam CPO.

Diagram sebab akibat menjelaskan faktor-faktor potensial yang menjadi penyebab kenaikan kadar ALB dalam produksi CPO. Berikut ini penjelasan dari masing-masing faktor:

\section{a. Bahan Baku}

Bahan baku sangat berpengaruh terhadap mutu dari produksi CPO, dalam hal ini bahan baku yang digunakan berupa tandan buah segar yang berasal dari perkebunan kelapa sawit. Hal yang harus diperhatikan dari bahan baku berupa tingkat kematangan buah, penempatan bahan baku di pabrik, dan proses pendorongan dengan loader.

\section{b. Tenaga Kerja}

Dalam meningkatkan mutu dari produksi $\mathrm{CPO}$, faktor tenaga kerja juga memiliki peranan yang sangat besar dalam menentukan mutu produksi. Dalam hal ini faktor tenaga kerja yang sangat berpengaruh terhadap mutu CPO yaitu berupa tingkat pendidikan, kedisiplinan, pelatihan, dan pengalaman dari pekerja.

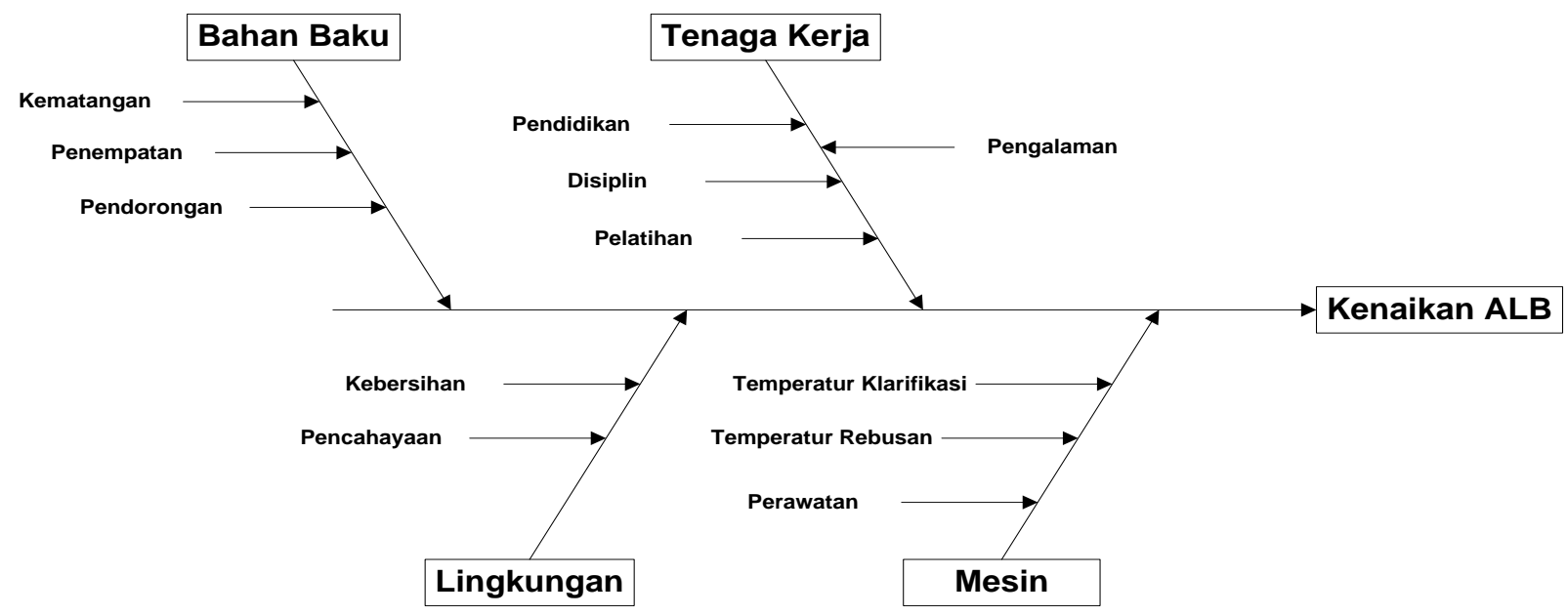

Gambar 2. Diagram Fishbone 


\section{c. Lingkungan}

Lingkungan kerja yang baik akan menghasilkan produk dengan mutu yang baik, karena dengan lingkungan yang baik akan tercipta kondisi kerja yang baik. Dalam hal ini yang menjadi fokus terhadap lingkungan kerja berupa tingkat pencahayaan dan kebersihan pabrik.

\section{d. Mesin}

Mesin merupakan faktor penting dalam menentukan mutu dari produksi CPO. Dalam hal ini faktor yang menjadi pengaruh berupa sistem perawatan mesin, dan menemukan setting optimum dari mesin untuk mendapatkan kemampuan proses secara maksimal.

\section{Tahap Improve}

Tahap ini bertujuan untuk meningkatkan kualitas dengan memperbaiki proses yang menjadi akar penyebab dari permasalahan. Proses identifikasi akar penyebab dari permasalahan yang mengakibatkan kenaikan kadar ALB dalam produksi CPO dapat dilihat pada fase analyze melalui diagram sebab akibat kenaikan kadar ALB:

\section{a. Perbaikan Kualitas Bahan Baku}

Dalam menghasilkan CPO dengan mutu baik, perlu dilakukan perbaikan terhadap kualitas bahan baku yang digunakakan. Perbaikan kualitas dari bahan baku mencakup penentuan kriteria tingkat kematangan buah, proses penempatan buah di pabrik, dan proses pendorongan buah dengan loader ke loading ramp.

\section{b. Tingkat Kematangan Buah}

Dalam mendapatkan tingkat kematangan buah yang baik, bagian sortasi buah harus diberi pengetahuan tentang pemilihan fraksifraksi buah yang baik untuk pengolahan. Dengan pengetahuan yang dimiliki bagian sortasi diharapkan tidak terdapat lagi buah yang mentah atau busuk dalam proses pengolahan. Fraksi buah yang baik digunakan untuk pengolahan yaitu berada pada fraksi 1, 2, dan 3 .

\section{c. Penempatan Buah}

Penempatan buah di pabrik, sebaiknya tidak ditumpuk terlalu tinggi. Berdasarkan diskusi dengan Bapak Novendri Assisten Pengolahan Pabrik penumpukan buah yang terlalu tinggi akan menyebabkan tekanan terhadap buah semakin besar, hal ini dapat menyebabkan kerusakan buah dikarenakan sifat fisik buah yang mudah terluka, selain itu penumpukan buah yang terlalu tinggi akan menyebabkan sistem FIFO (First In, First Out) dalam proses pengolahan tidak berjalan baik dikarenakan buah yang tertumpuk. Buah yang rusak akan mempengaruhi mutu dari CPO yang diproduksi, karena buah yang rusak akan mempercepat kenaikan kadar ALB.

Penempatan buah disarankan yang terlihat pada Gambar 3 menunjukkan penumpukan buah di pabrik pada tempat penerimaan buah tidak terlalu tinggi. Penumpukan buah seperti ini dapat mengurangi resiko buah mengalami kerusakan akibat buah terluka, hal ini dikarenakan buah tidak mengalami tekanan yang besar pada saat buah ditumpuk, selain itu penumpukan buah tidak terlalu tinggi juga memudahkan pendorongan buah dengan loader. Penumpukan buah seperti ini juga memudahkan penerapan sistem Penempatan FIFO

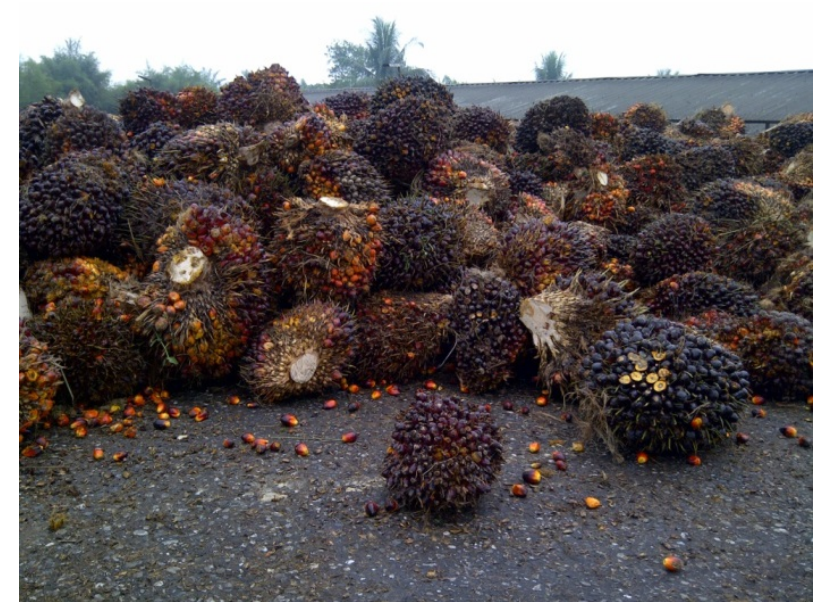

Gambar 3. Penempatan Buah yang Disarankan

Penempatan buah tidak disarankan yang terlihat pada Gambar 4 menunjukkan penumpukan buah di pabrik pada tempat penerimaan buah terlalu tinggi. Penumpukan buah seperti ini akan menyebabkan buah memiliki resiko tinggi mengalami kerusakan akibat buah terluka, hal ini dikarenakan buah mengalami tekanan yang besar disebabkan penumpukan buah yang terlalu tinggi. Penumpukan buah yang tinggi juga menyebabkan proses pendorongan buah dengan loader menjadi terhambat, selain itu juga 
menyulitkan penerapan sistem FIFO dalam pengolahan.

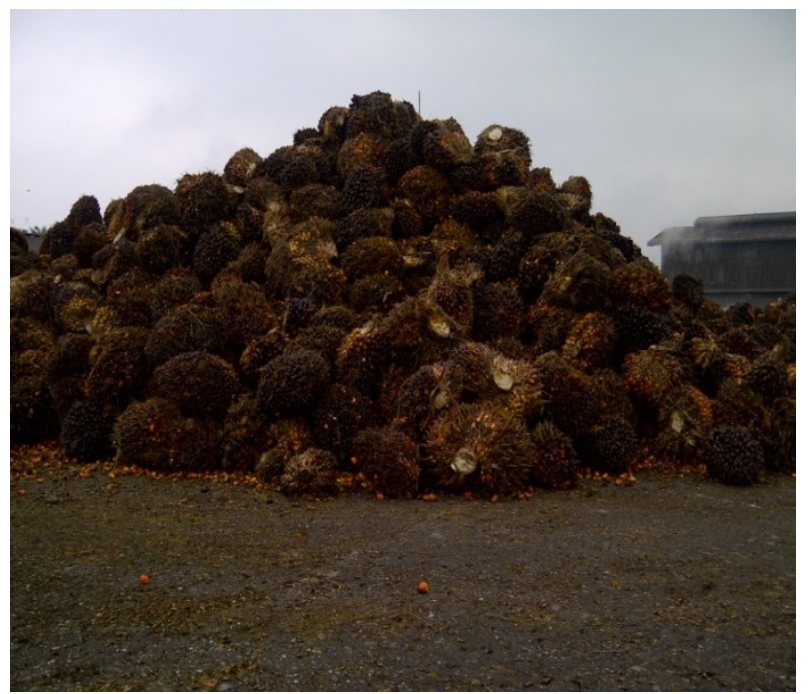

Gambar 4. Penempatan Buah yang Tidak Disarankan

\section{d. Pendorongan Buah dengan Loader}

Proses pendorongan buah dalam hal ini tandan buah segar yang digunakan sebagai bahan baku CPO dengan menggunakan loader sangat beresiko terjadinya kerusakan buah. Dalam meminimalkan kerusakan buah akibat dorongan dari loader maka keahlian dan keterampilan dari operator loader sangat dibutuhkan. Berdasarkan pengamatan di lapangan ada beberapa hal yang harus diperhatikan oleh operator loader dalam proses pendorongan buah yaitu operator loader harus memperhatikan mata pendorong dari loader diusahakan serendah mungkin dengan permukaan lantai hal ini untuk mengurangi resiko buah rusak akibat dorongan dari loader, kedua proses pendorongan dilakukan secara perlahan-lahan dengan menyisir tumpukan buah.

\section{e. Perbaikan Kualitas Tenaga Kerja}

Dalam meningkatkan mutu dari produksi CPO, faktor tenaga kerja juga memiliki peranan yang sangat besar dalam menentukan mutu CPO. Peningkatan kualitas dari tenaga kerja secara terus menerus dengan memberikan pelatihan untuk meningkatkan kinerja sangat disarankan, serta perlu dilakukan sistem promosi jabatan bagi tenaga kerja yang memiliki kinerja baik, dan demosi bagi tenaga kerja yang tidak memiliki kinerja baik.

\section{f. Perbaikan Kualitas Lingkungan}

Kebersihan lingkungan tempat kerja dan peralatan kerja akan menghambat kenaikan kadar ALB dalam CPO. Karena kadar ALB akan tinggi bila lingkungan kotor, hal ini dikarenakan bakteri akan mudah berkembang pada lingkungan yang kotor. Dalam menjaga lingkungan supaya tetap terjaga kebersihannya disarankan dilakukan pembersihan pabrik serta peralatan secara berkala, dan pengaturan pencahayaan yang baik.

\section{g. Perbaikan Kualitas Mesin}

Kerusakan mesin pada saat pengolahan akan menyebabkan penumpukan bahan baku. Penumpukan bahan baku akan menyebabkan kenaikan kadar ALB. Upaya untuk mencegah kerusakan mesin pada saat pengolahan yaitu dengan melakukan perawatan mesin secara berkala. Selain itu setting mesin yang baik akan mempengaruhi kemampuan

\section{KESIMPULAN}

Berdasarkan perhitungan kapabilitas proses diperoleh nilai Cpk sebesar 0,37 dan dikonversi ke level sigma sebesar 1,10. Dari nilai Cpk dan level sigma perusahaan saat ini disimpulkan tingkat kapabilitas proses perusahaan dan level sigma perusahaan masih sangat rendah.

Perbaikan untuk mengatasi permasalahan yang ada yaitu berupa perbaikan secara berkelanjutan sehingga dapat dilakukan suatu proses peningkatan mutu pada produksi CPO. Perbaikan yang dapat dilakukan sebagai berikut:

a). Perbaikan untuk bahan baku berupa penentuan tingkat kematangan buah berdasarkan fraksi buah., usahakan penempatan buah tidak terlalu tinggi, dan pelatihan untuk peningkatan keterampilan operator loader pada proses pendorongan buah.

b). Perbaikan untuk tenaga kerja yaitu dengan melakukan pemberdayaan secara maksimal terhadap tenaga kerja dengan memperhatikan tingkat pendidikan, disiplin, pelatihan, dan pengalaman. 
c). Perbaikan untuk lingkungan yaitu dengan melakukan pembersihan pabrik serta peralatan secara berkala, dan pengaturan pencahayaan yang baik.

d). Perbaikan untuk mesin yaitu dengan melakukan perawatan mesin secara berkala, dan melakukan setting optimum pada mesin.

\section{DAFTAR PUSTAKA}

[1] Pahan, Iyung. 2008. Panduan Lengkap Kelapa Sawit: Manajemen Agribisnis dari Hulu Hingga Hilir. Jakarta: Penebar Swadaya.
[2] Evans, James R. dan William M. Lindsay. 2007. An Introduction to Six Sigma \& Process Improvement: Pengantar Six Sigma. Jakarta: Salemba Empat.

[3] D. Manggala. 2005. Mengenal Six Sigma Secara Sederhana dalam www.beranda.net diakses pada 10/02/2012. 